\title{
Is It Really Worthwhile for a Brand to Eliminate Overpackaging? New Insights from Context Effects: An Abstract
}

\author{
Elisa Monnot, Fanny Reniou, Béatrice Parguel, and Leila Elgaieed
}

\begin{abstract}
Comparing an overpackaged product with a non-overpackaged product, experiments have shown that eliminating overpackaging may have an influence on brand image, consumers' attitude and purchase intention. However, these experiments did not consider the potential effects of competitors' strategies in terms of overpackaging when evaluating the impact of a target brand decision to eliminate overpackaging. In the present paper, we draw on context effects and attribution theories to consider that the influence of overpackaging elimination on consumers' response may depend on the absence vs. presence of overpackaging on the competing product. An experiment was conducted on 218 consumers. It demonstrates that overpackaging elimination will only be interrogated and attributed to low quality (1) when non-overpackaged products cohabit with overpackaged ones in the store shelves and (2) by non-environmentally concerned consumers. These results bear interesting recommendations for public policy makers and for CSR-sensitive companies.
\end{abstract}

References Available Upon Request

Acknowledgment This research is included in Movida Research Programme of French Ministry of Sustainable Development.

\footnotetext{
E. Monnot $(\bowtie) \bullet$ L. Elgaieed

Thema, CNRS UMR 8184, Université de Cergy-Pontoise, Cergy-Pontoise, France

e-mail: elisa.monnot@u-cergy.fr; leila.elgaaied@u-cergy.fr

F. Reniou

Institut de Recherche en Gestion, Université Paris-Est Créteil, Créteil, France

e-mail: fanny.reniou@u-pec.fr

B. Parguel

DRM UMR CNRS 7088, Université Paris-Dauphine, Paris, France

e-mail: beatrice.parguel@dauphine.fr 